Cadernos Metrópole (2018) v. 20, n. 41, pp. 209-222

ISSN impresso 1517-2422 - on-line 2236-9996

http://dx.doi.org/10.1590/2236-9996.2018-4110

\title{
RETRATAÇÃO
}

A equipe editorial da revista Cadernos Metrópole comunica a publicação formal de Retratação para extração do artigo:

BARBOSA, Raúl Felix e DADALTO, Maria Cristina (2018). Migración y la gobernanza global: el rol de las redes migrantes. Cadernos Metrópole. São Paulo, v. 20, n. 41, pp. 209-222.

http://dx.doi.org/10.1590/2236-9996.2018-4110

Desde que foi comprovado o plágio ao artigo:

TAYLOR, Sara Rose (2016). The role of migrant networks in global migration governance and development. Migration and Development, 5:3, 351-360, DOI: 10.1080/21632324.2015.1068504.

Lucia Bógus e Luiz César de Q. Ribeiro

Editores científicos

\section{Migración y la gobernanza global: el rol de las redes migrantes}

Raúl Felix Barbosa1', Maria Cristina Dadalto²

${ }^{1}$ Universidade Federal do Rio Grande do Sul, Porto Alegre, RS, Brasil

${ }^{2}$ Universidade Federal do Espírito Santo, Vitória, ES, Brasil. 
